\title{
Representations in the Sixteenth-Century Arithmetic Books
}

\author{
María José Madrid*, Alexander Maz-Machado, Carmen León-Mantero \\ Department of Mathematics, University of Cordoba, Spain
}

Copyright $(\mathcal{C} 2015$ by authors, all rights reserved. Authors agree that this article remains permanently open access under the terms of the Creative Commons Attribution License 4.0 International License.

\begin{abstract}
The research on the History of Mathematics and Mathematics Education has on textbook a useful tool to provide diverse types of information; this fact has led to the realization of many different studies focus on them. In this context, this work analyzes eight different sixteenth-century arithmetic books to know the different types of representations included in them. For this, it has used the historical analysis supported by the content analysis of textbooks. The results obtained show diversity between the representations included in each book. Even though verbal and numerical ones are part of every one of them, graphic representations vary from one book to another.
\end{abstract}

Keywords History of Mathematics Education, Sixteenth-Century, Arithmetic, Old mathematics Textbooks, Representation

\section{Introduction}

The importance of research about History of Mathematics and Mathematics Education is that it allows finding out and highlighting different moments, situations, institutions, people or topics which in a particular moment meant a change or an advance for both the History of Mathematics and the History of Mathematics Education [10].

Old textbooks have a relevant role in these studies, because in its pages there is different information about the habits, the society during the time when they were written, the mathematics in that period and even how that mathematics was taught. Schrubing [20, p.41] stated: "teaching practice is not so much determined by ministerial decrees and official syllabuses as by the textbooks used for teaching". This has motivated a large amount of studies which analyze historical textbooks like Glaeser [4], Sierra, González and López [21], Maz y Rico [11], Gómez [5].

This article is focused on the Sixteenth-century arithmetic books; these books were started to print in the end of the Fifteenth due to the development of the written press and were mainly a tool to help traders and businessman in their commercial trade. For that reason many of them appear in cities which were important commercial places and they contain only the mathematical knowledge that traders need, mainly in the form of problems. For example, they present exercises to calculate the value of different objects, to make monetary exchanges, share-outs, to solve problems about wages [13].

In addition, the contents of all this arithmetic books were pretty similar: Positional numeral system, algorithms for the basic operations with positive integers, basic fractions and operations with them, rule of three, progressions, some of them include also extracting square roots and cube roots and algebra [13].

In this context, the aim of this paper is to analyze the different representations which were part of eight sixteenth-century arithmetic books; all of them represent this practical trend, common during this century in Spain, of relating mathematics with business deals [15]; in order to help business people learning mathematics.

Verbal statements and visual organizations, graphic or symbolic, are the most used means in the emission, transmission and reception of mathematical knowledge, which gives them great importance in the processes of teaching and learning this subject. Particularly, representations are considered an essential part to analyze the teaching process and comprehension of mathematics [16]. For this different authors have studied them in history like González [7].

Representations are the symbolic or graphic notations, specifics for each notion, through which mathematics concepts and process and its more relevant properties and characteristics are expressed. This kind of representations is external, because they have a trace or a tangible physical support. Furthermore, external representations allow expressing or communicating the concepts or ideas to the people that uses them [3].

Gómez adds about systems of representations that they can be used to represent different aspects of a concept or mathematical structure [6].

Therefore, throughout this work it pretends to know the different ways in which the sixteenth-century authors of arithmetic books explain the concepts included in their works. 


\section{Methodology}

This research is exploratory and descriptive which historical-mathematical nature.

We have used primary sources and selected eight books, all of them written in Spanish and published during the sixteenth-century. These books had a large influence during this century and the followings; they were used to learn mathematics at universities, houses of trade, etc. Indeed, many of them had versions which were printed even in the XVIII-century.

The chosen books are: Conpusicion de la arte de la arismetica y Juntamente de geometría written by Juan de Ortega in 1512 [12], Sumario breve de la practica de arithmetica de todo el curso del arte mercantivol written by Juan Andres in 1515 [1], Arithmetica Practica written by Juan de Yciar in 1549 [23], Suma de Arihtmetica Practica y de todas Mercaderias con la horden de contadores written by Gaspar de Texeda in 1546 [22], Libro primero de Arithmetica Algebratica written by Marco Aurel in 1552 [2], Arte breve y muy provechoso de cuenta castellana y Arismetica written by Juan Gutierrez de Gualda in 1564 [8], Arithmetica written by Antich Rocha in 1564 [17] and Libro de arithmetica especvlativa, y práctica, intitvlado, el Dorado Contador written by Miguel Geronimo de Santa Cruz [19] (its first edition was published in 1594, but the one used in this work was printed in1625).

The methodology used to examine these books is the historical analysis supported by the content analysis of textbooks. All the paragraphs from the books have been considered analysis units, which have been read, categorized and finally analyzed.

\section{Results}

As it was stated before, representations in this work mean the signs, notations, figures or expressions through which mathematics are expressed [3]. In these books three general types of representation can be found, the classification made is based on the one suggested by Maz-Machado, López y Sierra [9]:

- Verbal representation: It is the main type of representation in the books. Most concepts, methods and properties are explained using words; for example, in Figure 1 is shown a verbal representation.

\section{T2articilo parmero ôla oifinició oel numero äbeado. $y$ bas oe faber que numero äbrado no csotra cofa fino numeróa tiene ms parte o 008/0treg/o mucbas partes oe vin entero pnotodas car fi todas las partes tuuiefíe noferia quebes/ do antes feria entero.sfitmefimo numero âbsadoes numero}

Figure 1. Verbal representation from Juan Andres' book (Page LVI).

- Numerical representation: This kind of representations is combined in general with verbal representations. The authors used numbers, lines and symbols to present different operations, exercises, examples... Figure 2 shows an example of numerical representation.

$$
\begin{aligned}
& 15|z 0| 18|16| 1 z \quad 10|18 z 316| 1 z|z| \\
& \frac{5}{8} \frac{5}{6} \frac{3}{4} \frac{z}{3} \frac{1}{2} \cdot 5 \cdot \frac{5}{8} \quad \frac{5}{12} \frac{5}{4} \frac{5}{5} \frac{1}{2} 8 \\
& z 4 \\
& z 4 \\
& 130
\end{aligned}
$$

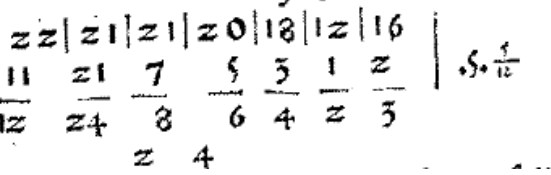

Figure 2. Numerical representation in Ortega's book (Page 48).

- Graphical representation: These representations include tables, figures, geometric representations, diagrams and mixed representations.

\begin{tabular}{|c|c|c|c|c|c|c|c|c|c|}
\hline 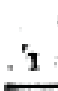 & & 2 & $\begin{array}{r}3 \\
3 \\
\end{array}$ & $\begin{array}{l}4 \\
4 \\
\end{array}$ & 5 & $\begin{array}{l}6 \\
6\end{array}$ & $\begin{array}{l}7 \\
7\end{array}$ & $\begin{array}{l}8 \\
8\end{array}$ & $\begin{array}{l}9 \\
9 \\
\end{array}$ \\
\hline & 1 & 4 & $\begin{array}{l}6 \\
3 \\
\end{array}$ & $\begin{array}{l}8 \\
4\end{array}$ & \begin{tabular}{|c|}
110 \\
5
\end{tabular} & $\begin{array}{c}1.2 \\
6\end{array}$ & $\begin{array}{c}14 \\
7 \\
\end{array}$ & $\begin{array}{c}16 \\
8\end{array}$ & $\begin{array}{c}18 \\
9 \\
\end{array}$ \\
\hline 3 & $\begin{array}{l}3 \\
1 \\
\end{array}$ & 2 & $\begin{array}{l}9 \\
3 \\
\end{array}$ & $\begin{array}{r}12 \\
4\end{array}$ & $\begin{array}{l}15 \\
5 \\
\end{array}$ & $\begin{array}{c}18 \\
6\end{array}$ & $\begin{array}{c}21 \\
7\end{array}$ & $\begin{array}{c}24 \\
8\end{array}$ & $\begin{array}{c}27 \\
9\end{array}$ \\
\hline 4 & 4 & $\begin{array}{l}8 \\
2\end{array}$ & $\begin{array}{c}12 \\
3\end{array}$ & $\begin{array}{c}16 \\
4\end{array}$ & \begin{tabular}{|c|}
$\frac{1}{20}$ \\
5
\end{tabular} & $\begin{array}{c}24 \\
6\end{array}$ & $\begin{array}{c}28 \\
7\end{array}$ & $\begin{array}{c}32 \\
8\end{array}$ & $\begin{array}{c}36 \\
9\end{array}$ \\
\hline 5 & $\begin{array}{l}S \\
1\end{array}$ & $\begin{array}{c}10 \\
2 \\
\end{array}$ & $\begin{array}{c}15 \\
3 \\
\end{array}$ & $\begin{array}{c}20 \\
4\end{array}$ & \begin{tabular}{|c|}
25 \\
5
\end{tabular} & $\begin{array}{c}30 \\
6\end{array}$ & $\begin{array}{r}35 \\
7 \\
\end{array}$ & $\begin{array}{c}40 \\
8\end{array}$ & $\begin{array}{c}45 \\
9 \\
\end{array}$ \\
\hline 6 & $\begin{array}{l}6 \\
1\end{array}$ & $\begin{array}{c}12 \\
2\end{array}$ & $\begin{array}{c}18 \\
3 \\
\end{array}$ & $\begin{array}{c}24 \\
4 \\
\end{array}$ & 30 & $\begin{array}{l}36 \\
6 \\
\end{array}$ & $\begin{array}{c}42 \\
7\end{array}$ & $\begin{array}{c}48 \\
8 \\
\end{array}$ & $\begin{array}{c}54 \\
9 \\
\end{array}$ \\
\hline 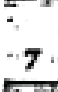 & ? & $\begin{array}{r}14 \\
2 \\
\end{array}$ & $\begin{array}{c}21 \\
3\end{array}$ & $\begin{array}{c}28 \\
4\end{array}$ & 35 & $4^{42}$ & $\begin{array}{c}49 \\
7 \\
\end{array}$ & $\begin{array}{l}56 \\
18 \\
\end{array}$ & $\begin{array}{r}63 \\
9 \\
\end{array}$ \\
\hline & $\begin{array}{l}8 \\
1\end{array}$ & $\begin{array}{c}16 \\
? \\
\end{array}$ & $\begin{array}{l}24 \\
3 \\
\end{array}$ & $\begin{array}{l}32 \\
4 \\
\end{array}$ & $\begin{array}{c}40 \\
5\end{array}$ & $\begin{array}{r}148 \\
6 \\
\end{array}$ & $\begin{array}{l}56 \\
7 \\
\end{array}$ & $\begin{array}{r}164 \\
18 \\
\end{array}$ & $\begin{array}{c}72 \\
9 \\
\end{array}$ \\
\hline & $\begin{array}{l}9 \\
1 \\
\end{array}$ & $\begin{array}{c}18 \\
2 \\
\end{array}$ & $\begin{array}{r}27 \\
3 . \\
\end{array}$ & $\begin{array}{l}36 \\
4\end{array}$ & 5 & 154 & $\left\{\begin{array}{l}63 \\
7\end{array}\right.$ & $7_{8}^{2}$ & \\
\hline
\end{tabular}

Tables and diagrams are used to present assembled information which helps readers to understand the different contents. For example, in Figure 3 and 4 there are two examples of different multiplication tables included in the books.

Figure 3. Multiplication table in Rocha's book (Page 28). 


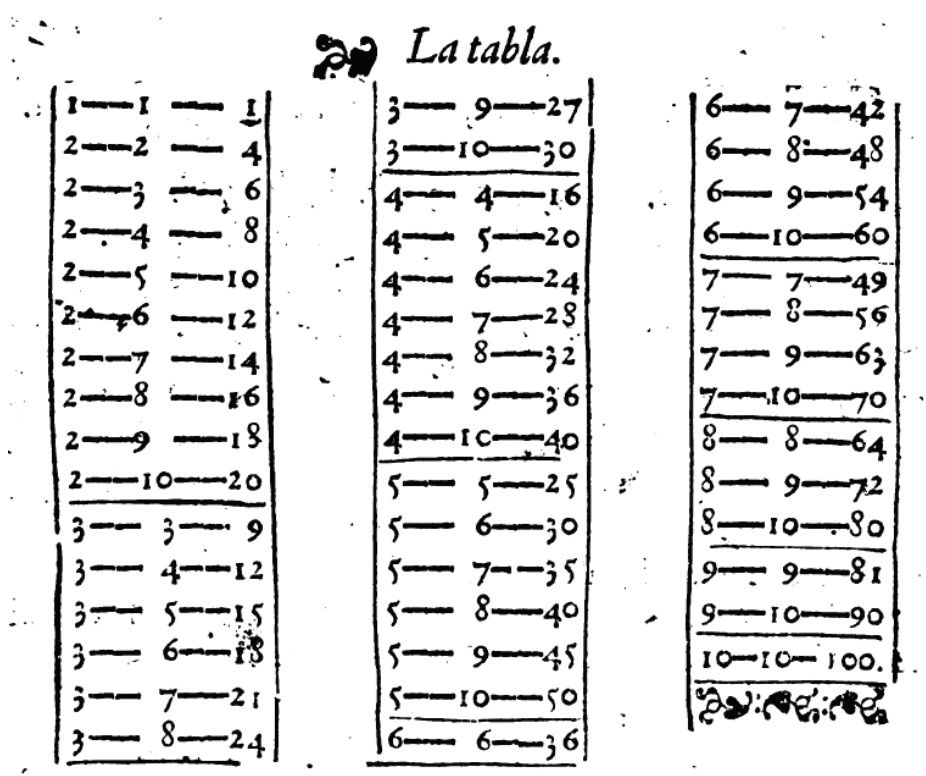

Figure 4. Multiplication table in Marco Aurel's book (Page 5).

Figures are used to illustrate the contents of the books, mainly geometric ones, like Figures 5 and 6.
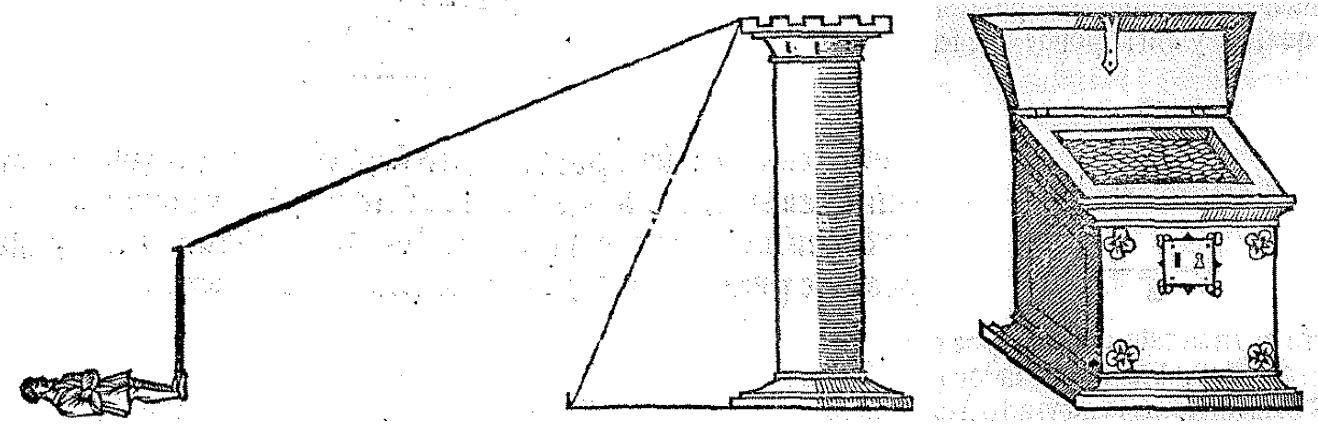

Figure 5. Figures from both Yciar's book (Page XLIIII) and Gutierrez.
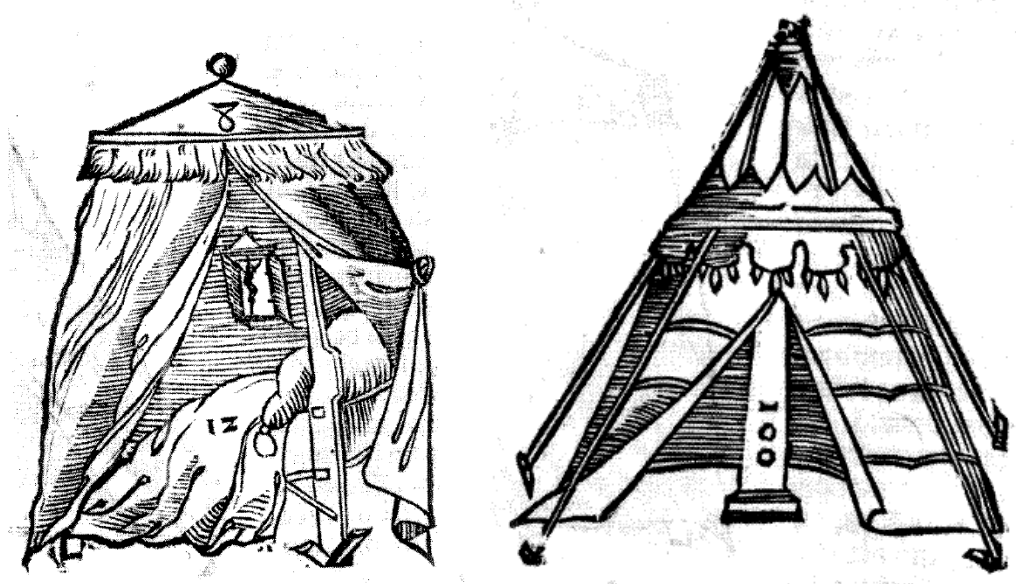

Figure 6. Figures from Texeda's book (Page XLIIII).

They use geometric graphics, which are, in general, basic polygons, to explain concepts which relate to square roots, like in Figure 7. 

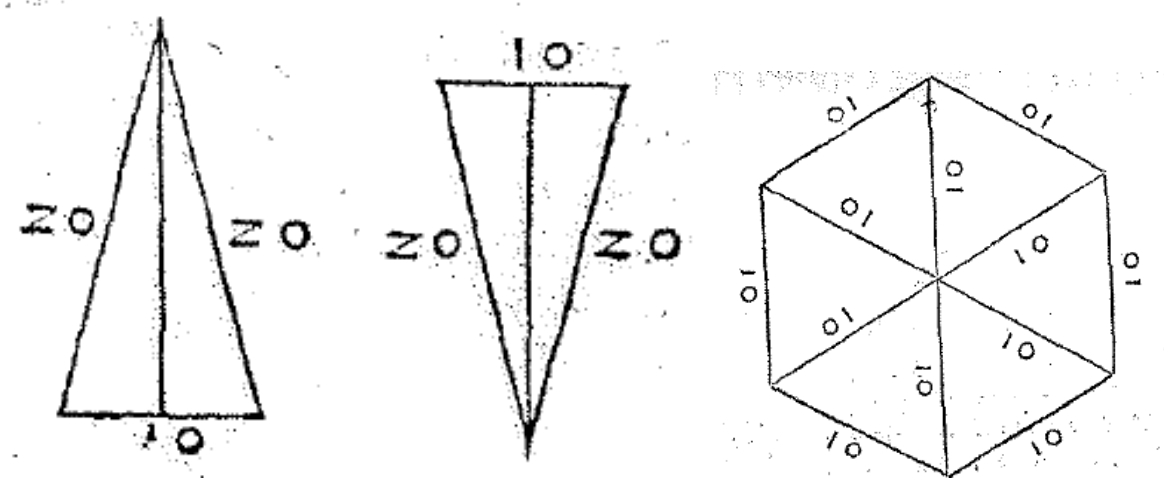

Figure 7. Triangles (Page 194) and a hexagon (Page 202) from Ortega's book.

In mixed graphics, it presents numbers, words, lines or brackets combined, like in Figure 8.

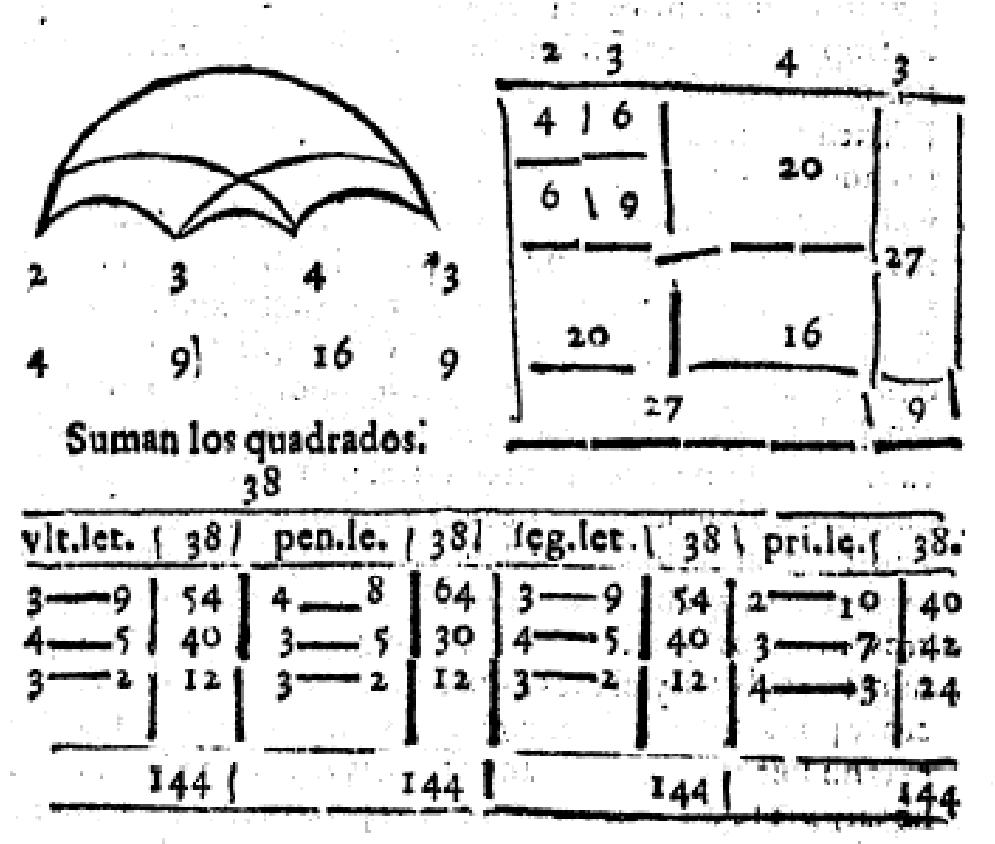

Figure 8. A mixed representation from Miguel Geronimo de Santa Cruz's book (Page 163).

To sum up, the following table (1) shows the different types of representations included in the books.

Table 1. Representations in the Sixteenth-Century books

\begin{tabular}{|c|c|c|c|c|c|c|c|}
\hline \multirow{3}{*}{ AUTHORS } & \multicolumn{7}{|c|}{ REPRESENTATIONS } \\
\hline & \multirow{2}{*}{ Verbal } & \multirow{2}{*}{ Numerical } & \multicolumn{5}{|c|}{ Graphics } \\
\hline & & & Tables & Geometric & Figures & Diagrams & Mixed \\
\hline Juan de Ortega & $\mathbf{x}$ & $\mathbf{X}$ & $\mathbf{x}$ & $\mathbf{x}$ & & & $\mathbf{X}$ \\
\hline Juan Andrés & $\mathbf{X}$ & $\mathbf{X}$ & $\mathbf{X}$ & $\mathbf{X}$ & $\mathbf{X}$ & & $\mathbf{X}$ \\
\hline Juan de Yciar & $\mathbf{x}$ & $\mathbf{X}$ & $\mathbf{X}$ & $\mathbf{X}$ & $\mathbf{X}$ & & $\mathbf{X}$ \\
\hline Gaspar de Texada & $\mathbf{X}$ & $\mathbf{X}$ & $\mathbf{X}$ & $\mathbf{X}$ & $\mathbf{X}$ & & $\mathbf{X}$ \\
\hline Marco Aurel & $\mathbf{X}$ & $\mathbf{X}$ & $\mathbf{X}$ & & & & \\
\hline Juan Gutiérrez & $\mathbf{X}$ & $\mathbf{X}$ & $\mathbf{X}$ & & $\mathbf{X}$ & & \\
\hline Antich Rocha & $\mathbf{X}$ & $\mathbf{X}$ & $\mathbf{X}$ & $\mathbf{X}$ & & $\mathbf{X}$ & \\
\hline $\begin{array}{l}\text { Miguel Gerónimo de } \\
\text { Santa Cruz }\end{array}$ & $\mathbf{X}$ & $\mathbf{X}$ & $\mathbf{X}$ & $\mathbf{X}$ & & $\mathbf{X}$ & $\mathbf{X}$ \\
\hline
\end{tabular}


This table shows the supremacy of verbal and numerical representations; they are not only part of every book, but also the main types of representation in them. However, the analysis of graphic representations shows more diversity, because apart from tables, none of the other types of graphic representations can be found in all the books.

Diagrams and figures are the less present in the books. Only one diagram can be found in Santa Cruz and Rocha's books and apart from Juan de Yciar, Gaspar de Texeda and Juan Gutierrez who include several figures in their books, Juan Andres include only two pages with figures.

Futhermore, opposite to Juan de Yciar, Gaspar de Texeda or Juan Gutierrez who include figures to help understanding geometric problems, Juan Andres include in its two pages a serie of hands which represents different numbers. Picatoste [14] states these sheets reffer to the dactylology or art of finger-counting.

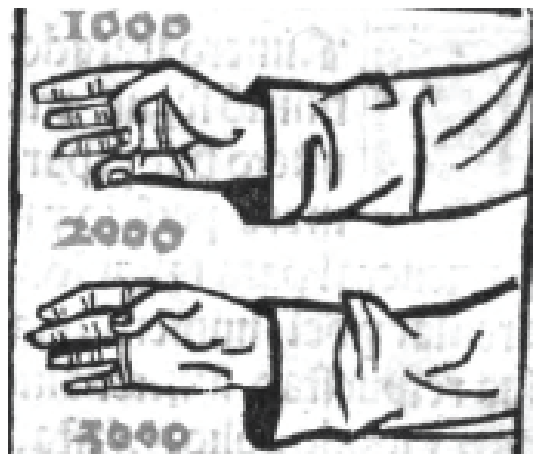

Figure 9. Figure in Juan Andres'book.

Another remarkable fact is that all figures which appear in Juan Gutiérrez' book appear also in Juan de Yciar's one. This may be because this edition of Juan Gutierrez' book appeared joined to one of Juan de Yciar's calligraphy which was also published in 1564, so it is possibble that he copied the figures from Juan de Yciar's arithmetic book, which was published in 1549, but Gutierrez wrote other arithmetic books previously $[14,18]$ and in fact before Yciar's arithmetic book and we don't know if those previous editions contain these figures. Another possibility could be that these figures were part of the same printing press, because both books from Yciar [23] and Gutierrez [8] were printed in Zaragoza and in Pedro Bernuz' house, so maybe they just reused the figures they had already printed.

Finally, Marco Aurel and Juan Gutierrez are the ones who present a smaller number of graphical representations; indeed in Aurel's book only tables can be found, and in Gutiérrez's book only tables and figures. On the other hand, Juan de Yciar, Gaspar de Texeda, Miguel Geronimo de Santa Cruz and Juan Andres show six of the seven different categories considered.

\section{Conclusions}

Several arithmetic books written with mercantile aim were well-known during the sixteenth-century and even in the following centuries. These books play a key role helping business man, traders, etc. learning basic mathematics which were necessary to improve their business, avoid deceptions, etc. in a time in which the commerce started to grow. These reasons have motivated the realization of this study about representations in the different books.

In addition, representations are used to communicate the different mathematical concepts; during this study it has been found out that representations were not too similar in the books. Verbal and numerical are the main type of representation in all of them, the authors use them to express most concepts and examples.

Along with these two types in the books there are graphic representations, but apart from tables no other graphic representations appear in all the books. The different authors showed different ways of explaining similar contents, for example, authors like Juan de Yciar or Gaspar de Texeda used figures to help understand geometric problems, Miguel Geronimo de Santa Cruz and Antich Rocha include diagrams to sum up the contents.

Some of the possible next steps in this research will be studying the mathematical contents of the books, comparing them to know the main differences and similarities between them, to see how they influence each other, etc.

\section{Acknowledgements}

This work has been realized inside the research project of the $\mathrm{R}+\mathrm{D}+\mathrm{i}$ Plan for the Ministry of Economy and Competitiveness of Spain EDU2011-27168.

\section{REFERENCES}

[1] J. Andres. Sumario breve de la practica de la arithmetica, Juan Joffre, Valencia, 1515.

[2] M. Aurel. Libro Primero de Arithmetica Algebratica, casa de Ioan de Mey Flandro, Valencia, 1552.

[3] E. Castro, E. Castro. Representaciones y modelización. En Rico, L. (coord.), La educación matemática en la enseñanza secundaria, 95-124, Horsori, Barcelona, 1997.

[4] G. Glaeser. Epistémologie des nombres relatifs, Recherches en Didactique des Mathématiques, Vol.2, No.39, 303-346, 1981.

[5] B. Gómez. El análisis de manuales y la identificación de problemas de investigación en Didáctica de las Matemáticas, PNA, Vol.5, No.2, 49-65, 2011.

[6] P. Gómez. Análisis didáctico y diseño curricular en matemáticas, Revista EMA, Vol.7, No.3, 251-292, 2002.

[7] M.T. González. Sistemas de representación en la enseñanza de los puntos críticos: perspectiva histórica, Revista Dialogo Educacional, Vol.6, No.8, 145-160, 2006. 
[8] J. Gutierrez. Arte Breve y muy provechoso de quenta castellana y Arithmetica, casa de Pedro Bernuz, Zaragoza, 1564.

[9] A. Maz-Machado, C. López, M. Sierra. Fenomenología y representaciones en la Arithmetica de Juan de Yciar. En L. Rico L., Cañadas, M. C., Gutiérrez, J., Molina, M. y Segovia, I. (Eds.), Investigación en Didáctica de las Matemática. Homenaje a Encarnación Castro, pp. 77-84, Editorial Comares, Granada, 2013.

[10] A. Maz-Machado, L. Rico. Tratado elemental de matemáticas, de José Mariano Vallejo, en el bicentenario de su publicación, Suma, Vol.74, 55-63, 2013.

[11] A. Maz, L. Rico. Negative numbers in the 18th and 19th centuries: phenomenology and representations, Electronic Journal of Research in Educational Psychology, Vo1.7, No.1, 537-554, 2009.

[12] J. de Ortega. Conpusicion de la arte de la arismetica y Juntamente de geometría, casa de Maistro Nicolau de Benedictis, León, 1512.

[13] J. Paradís, A. Malet. La génesis del álgebra simbólica. (Vol. I). Los orígenes del álgebra: De los árabes al Renacimiento, PPU, Barcelona, 1989.

[14] F. Picatoste. Apuntes para una biblioteca científica española del siglo XVI; estudios biográficos y bibliográficos de ciencias exactas físicas y naturales y sus inmediatas aplicaciones en dicho siglo, Manuel Tello, Madrid, 1891. Online available from http://bibliotecadigital.jcyl.es/i18n/consulta/registro.cmd?id= 13965
[15] J. Rey Pastor. Los matemáticos españoles del siglo XVI, Biblioteca Scientia, 2, 1926.

[16] L. Rico. Sobre las nociones de representación y comprensión en la investigación en educación matemática, PNA, Vol. 4, No.1, 1-14, 2009.

[17] A. Rocha. Arithmetica, casa de Claudio Bornat a la Águila Fuerte, Barcelona, 1564.

[18] V. Salavert. Introducción a la historia de la aritmética práctica en la Corona de Aragón en el siglo XVI, DYNAMIS, Vol.10, 63-911, 1990.

[19] M.G. de Santa Cruz. Libro de arithmetica especvlativa, y práctica, intitvlado, el Dorado Contador, contiene la fineza y reglas de contar oro y plata, y los Aneajes de Flandes, Viuda de Alonso Martín, Madrid, 1625.

[20] G. Schubring. On the methodology of analysing historical textbooks: Lacroix as textbook authors, For the learning of mathematics, Vol.7, No.3, 41-51, 1987.

[21] M. Sierra, M.T. González, C. López. El concepto de continuidad en los manuales españoles de enseñanza secundaria de la segunda mitad del siglo XX, Educación Matemática, Vol. 15, No.1, 21-49, 2003.

[22] G. de Texeda. Suma de Arihtmetica Practica y de todas Mercaderias con la horden de contadores, Oficina de Francisco Fernández de Córdoba, Valladolid, 1546.

[23] J. de Yciar. Arithmetica Practica, casa de Pedro Bernuz, Zaragoza, 1549. 